\title{
SUID-AFRIKA SE DILEMMA: UITDAGINGS EN GELEENTHEDE*)
}

Prof. dr. WP Robbertse, Dept. Wiskunde en Toegepaste Wiskunde, P.U. vir C.H.O.

$U$ ontvang vanaand almal sertifikate wat as bewys sal dien dat $u$ 'n graad verwerf het na volgehoue studie van minstens drie jaar. $U$ moes baie toetse en 'n hele aantal eksamens slaag. Hierdie eksamens en evalueringstoetse is telkens gestel om $u$ kennis te meet, naamlik die kennis wat u veronderstel was om van die bepaalde vak te verwerf het. En $u$ het finaal geslaag: $u$ het daardie veronderstelde kennis, inderdaad verwerf. Nou kom die groot vraag, seker die allerbelangrikste vraag wat ek vanaand aan $\mathrm{u}$ kan stel: wat gaan u met die verworwe kennis maak? Inderdaad ja, $u$ het na die Universiteit gekom om $u$ voor te berei vir die lewe. U wil as $u$ hiervandaan vertrek (om dit nou maar gewoonweg te stel) toeberei wees om " 'n lewe te gaan maak", vir uself 'n lewe te gaan verdien. Is ek reg, of wil u, as u hiervandaan vertrek, die kennis wat $u$ verwerf het gaan aanwend in diens van andere, d.w.s. van $u$ naaste, die volk van wie $u$ lid is, die land waarin $u$ woon en wat ons almal liefhet?

Hoe dit ook al sy, u sal baie gou uitvind dat u nog maar in die poorte van die wetenskap beland het, slegs nog maar 'n begin gemaak het, maar laat ek dit dadelik sê, 'n baie goeie begin. En met die besef dat u slegs maar nog 'n begin gemaak het, sal ook die oorweldigende besef daag: ek staan voor geweldige uitdagings maar ook geweldige geleenthede. En hierin is u gelukkig: die uitdaging is byna oorweldigend, maar die geleenthede legio.

Wat is nou die uitdaging waarna hier verwys word? En wat is die geleenthede?

Dit word deesdae meermale gesê a $t$ daardie volk of nasie wat die stryd binne die natuurwetenskaplike-tegniese arena wen, die stryd van die twintigste eeu wen. Hier word gerep van die stryd van die twintigste eeu. Daarby wil ek nie stilstaan nie. Ons weet almal genoeg daarvan, die teëstellinge, stryd en botsings tussen volkere van die wêreld: die Marxisme teen die Demokrasie, Marxisme teen die Christendom, die Liberalisme teen die Totalitarisme, Permissiwiteit teen die behoudende, e.s.m., e.s.m.

* Rede by geleentheid van die gradeplegtigheid van die Fakulteite Natuurwetenskappe en Teologie van die PU vir CHO op 25 Maart 1980. 
Hierdie botsing vind plaas en die stryd word gevoer (soos vir ons aldag op die hart gebind word) nie in die eerste plek met wapens, masjiengewere, tenks, kanonne, vuurpyle, vliegtuie en duikbote nie. Dit word gevoer op 'n veel subtieler wyse: dit gaan om die hart, die gemoed, ja die siel van die mens.

Die term "die totale aanslag op Suid-Afrika" is vir ons alombekend. Dit gaan vir ons om ons bestaan in die allesomvattende sin: fisiese geweld teen ons (van watter familie was daar nie al 'n seun op die grens nie?), subtiele morele regstreekse aanslag op die hart, die gemoed en verstand. Is die term "geestelike weerbaarheid" nie ook aan ons almal bekend nie?

Wat hierdie botsing en aanslag betref is daar sekere faktore wat ons nie mag miskyk nie.

Fisies weerbaar, ja dit moet ons wees; ook geestelik weerbaar. Maa lie sosiologiese agter- en ondergrond van ons dilemma, van die totale aanslag teen ons, mag ons nie miskyk nie. Ek wil dit nie sosio-polities of sosio-ekonomies noem nie, omdat ek die aandag op die sosiologiese wil vestig, hoewel my kwalifikasie miskien nie honderd persent reg mag wees nie. As ons na die evolusie in die ontwikkelings gang van die volkere van ons planeet kyk, dan tref dit ons keer op keer hoedat in die kom en gaan van volkere en nasies, wat ek wil noem 'n sekere sosiologiese proses hom steeds maar voltrek: in 'n mindere of meerdere mate op klein en op groot skaal. Ek gaan in die verband slegs twee voorbeelde noem.

\section{Die Franse revolusie}

Antwoord maar vir uself dié vraag: wat is die toestande wat in Frankryk geheers het voor die revolusie? Ofte wel: watter toestande het aanleiding gegee tot die revolusie: armoede, honger en ellende onder die proletariaat? Ek vra!

Voorbeeld nommer twee: Die Bolsjewistiese revolusie in Rusland in 1917! Ek vra nie: wat was die oorsake van die revolusie nie? Ek vra watter toestande het aanleiding gegee tot die revolusie? Was dit dalk ook weer armoede, honger en ellende onder die proletariaat?

Ek kan nog talle dergelike voorbeelde noem, d.w.s. voorbcelde waar 'n dergelike ommekeer in die volkshuishouding, 'n ommekeer in 'n ewe radikale of mindere radikale mate nie begryp of verklaar kan word as dit nie teen hierdie sosiologiese agter- en ondergrond gesien word nie. Ek wil egter ook nou nie beweer dat ek 
hier 'n soort van deterministiese proses sien nie, d.w.s. 'n proses wat, kom wat wil, voltrek sal word waar daar dergelike toestande heers nie. Alles hang af van wat juis die heersende groep van die besondere omstandighede maak. Maar tog nog die opmerking: ek, en waarskynlik u ook, het sowat 'n maand gelede oor die radio geluister na 'n vraag-antwoord-gesprek wat 'n korrespondent met 'n persoon wat 'n minister in die eertydse Rhodesiese kabinet was, gevoer het. Toe aan hom gevra is (dit was net nadat dit bekend geword het dat mnr. Mugabe die verkiesing so oorweldigend gewen het) waarom sake so verloop het soos wat die geval was, was een van sy antwoorde: "Te $\min$ te laat, d.w.s. ons het te min te laat gedoen".

En waar staan ons in die R.S.A.? Ons hoor, soos reeds gestel, vroeg en laat oor die radio en die televisie en ons lees in ons koerante van "die totale aanslag" teen ons. Wat is alles vir ons op die spel? Besef ons voor watter uitdaging ons hier staan? Moet ons nie met alles wat ons besit, ons kennis, ons kundigheid, al die kragte van ons gemoed en ons verstand op hierdie uitdaging afgaan om oplossings vir ons probleme te vind nie?

$U$ is nou gegradueerdes uit 'n universiteit! $U$ is die meningvormers, die beleidmakers van móre. Ons is seker daartoe geroepe om ons in hierdie saak voorwaar nie onbetuig te laat nie.

Wat juis hierdie uitdaging betref, rus daar 'n swaar en onontkombare verantwoordelikheid op ons, d.w.s. ook u skouers - ons sal ons deel moet, ek sê mót, bring.

U sal nou, dis voor-die-hand-liggend, dadelik vra: maar wat moet ek dan nou doen om my deel te bring? Hierdie vraag wil ek nie vir u probeer beantwoord nie. Dit moet $u$ vir uself doen. Wanneer $u$ dit vir uself probeer doen, sal $u$ uitvind voor watter formidabele taak u staan, maar 'n taak wat ook in sy uitdaging aan ons wonderlike geleenthede en grootse vergesigte bied.

Laat ons enkele aspekte van wat ek wil noem, ons dilemma, effens nader bekyk.

\section{Vertegniseerde maatskappy}

Ons lewe in 'n vertegniseerde maatskappy. Die term "die tegnokrasie van ons tyd" is aan ons almal bekend. Hierdie tegnokrasie is die kind van die natuurwetenskap en die tegniek. Om egter te besef hoedanig die natuurwetenskap en die tegniek ons hele samelewingspatroon determineer, kan ons maar net kyk na ons gewone huishouding: ons eetgerei, die elektriese stoof, die elektriese ketel, die elektriese 
gloeilamp, die stofsuier, die tafels en stoele, die bed waarop ons slaap, die matte, die skoene en klere wat ons aantrek, die pen waarmee ek skryf, die koerant wat ek lees, die radio, die televisiestel - alles is produkte van die natuurwetenskap en die tegniek.

Buite ons huis is die prent dieselfde: ek noem ons motorkarre, ons vliegtuie, ons fabrieke, ons winkels, ons kommunikasiewese, ons wapentuig (dink aan die kernbomme en interkontinentale missiele), om nie eers te praat van al die "byna". wonderwerke wat in ons mediese veld vandag plaasvind nie: anti-biotika, hartoorplantings, en nog meer.

Inderdaad, die natuurwetenskap en die tegniek het wat die persoonlike fisiese welstand van die mens betref, radikale veranderinge teweeggebring.

Met hulle vlerke gesprei oor die kontinente, het die natuurwetenskap en die tegniek binne ' $n$ betreklike kort tyd die lewensniveau van die mens laat styg tot die huidige ongekende vlak en, wat uiters belangrik is, die aardbol laat oorstroom deur mensemassas. Ja, menslik gesproke, is dit die natuurwetenskap en die tegniek wat grotendeels, byna uitsluitlik, verantwoordelik is vir die geweldige bevolkingsaanwas oor ons hele planeet.

Kom ons bekyk hierdie saak as een van ons groot probleme so 'n bietjie van nader.

\section{Die bevolkingsaanwas}

Voor die jaar 1750 het dit die wêreldbevolking sowat 1700 jaar geneem om te verdubbel; tussen 1750 en 1900 sowat 150 jaar, tussen 1900 en 1965 sowat 65 jaar en teen die middel -70 's was die geskatte tydperk sowat 35 jaar (Sadie, 1974, p. 21). En dis belangrik dat ons sal kennis neem van hierdie krimping van die verdubbelingstye.

Die wêreldbevolking tel vandag nagenoeg 3900 miljoen siele. Volgens die huidige groeitendens sal dit teen die jaar 2000 dan ongeveer 7800 miljoen wees, d.w.s. sowat verdubbel.

Dit is waar dat daar tans 'n afplatting van die bevolkingsgroei in o.a. Wes-liuropa is. Dit is die tendens, min of meer, in al die ontwikkelde lande. In die laaste tien jaar het die vrugbaarheid (d.w.s. aanwastempo) in baie Europese lande skerp gedaal. In sommige van die lande het die daling so ver gegaan dat die aantal sterftes 
begin het om de aantal geboortes te oortref en is 'n werklike daling in die bevolking geregistreer (Raad van Europa, 1976, voorwoord).

Akinbode (1977, p. 28) wys daarop dat die bevolking van Afrika tussen 1750 en 1850 op ongeveer 100 miljoen gebly het. Tussen 1850 en 1950 moes die bevolking van Afrika verdubbel het. Sedert 1950 was die aanwas konstant hoog. Die geskatte groeitempo van die bevolking in die hele Afrika en in elkeen van sy hoofgebiede was sedert 1950 groter as die gemiddelde 1,9 persent per jaar vir die hele wéreld. Met 'n kwart van die aarde se landoppervlakte het Afrika in 1970 slegs 344 miljoen mense gehad, d.w.s. 9 persent van die totale bevolking van die wêreld. Nogtans ondervind die kontinent tans die begin van 'n verstommende bevolkingsgroei wat kan opbou tot byna ondenkbare afmetings nog voor die end van die eeu. Die streke wat die grootste demografiese groei ervaar, is die noordelike en suidelike punte van die kontinent naamlik die Maghrebkus, Egipte en Suid-Afrika.

In 1904 het die Republiek van Suid-Afrika 'n bevolking van ongeveer 5,2 miljoen gehad; in 1970 het dit gegroei tot 21,4 miljoen, d.w.s. 'n groei van meer as 400 persent in 66 jaar.

Die bevolking van die hele gebied suid van die Sahara kan aangroei tot die $500 \mathrm{mil}$ joen-kerf teen die jaar 2000, en die van die hele Afrika tot 860 miljoen. Die hele Afrika se geskatte groei sal dan tussen 1970 en die jaar 2000 sowat 177 persent wees. In vergelyking met die ander lande, selfs ook dié wat die hoogste bevolkings. groei op ons aardbol het (Asië - 139 persent en die Unie van die Verenigde Sowjet Republieke - 72 persent), vind die groei van die bevolking van Afrika plaas teen 'n byna verbysterende tempo.

Dit is ongetwyfeld so dat sover ons kennis strek die mensdom nog nooit in sy geskiedenis so 'n groeitempo ondervind het soos tans die geval is nie. Iedere dag kom daar 220000 monde by wat gevoed moet word en in een jaar dus sowat 80 miljoen - genoeg om die hele bevolking van België, Luxemberg, Nederland en Frankryk te vervang (Sadie, 1974, p. 21).

Maar laat ons die bevolkingstoedrag in ons eie land nog enigsins nader bekyk. 
GEPROJEKTEERDE TOTALE BEVOLKING (volgens Sadio, 1973, p. 37 e.v.)

\begin{tabular}{lrrr} 
& \multicolumn{1}{c}{1970} & 2000 & \multicolumn{2}{l}{2020} \\
Blankes & 3822000 & 6890000 & 9204000 \\
Asiërs & 651000 & 1215000 & 1617000 \\
Kleurlinge & 2097000 & 4890000 & 7720000 \\
Bantoes (Swartes) & 15468000 & 37293000 & 62798000
\end{tabular}

Volgens Sadie dui die bevolkingsprojeksies, waarby aangeneem word dat die aannames t.o.v. die aanwastempo verwesenlik gaan word, daarop dat 'n toevoeging van 28 miljoen persone tussen 1970 en die einde van die eeu tot die bestaande 1970 - bevolking van 22 miljoen gaan plaasvind. Gedurende die eerste twee dekades van die een-en-twintigste eeu sal 'n verdere 31 miljoen bygevoeg word om die totale bevolking op 81 miljoen te staan te bring. Gedurende die eersvolgende dertig jaar sal ons derhalwe in staat wees om agt-en-twintig metropole van 'n miljoen inwoners elk of ses-en-vyftig stede van 500000 inwoners, elk, te vul.

Hoe staan dit met ons skoolbevolking?

Omdat ek nie die getalle ook vir die ander provinsies in die hande kon kry nie gee ek wat die blankes betref net die syfers vir Transvaal. Wat die swartman betref gee ek die syfers vir die hele Republiek, insluitende Transkei en Bophutatswana:

TOTALE SKOOLBEVOLKING (GRAAD I TOT ST. 10)

$\begin{array}{lrrrrr} & 1960 & 1970 & 1978 & 1979 & 1980 \\ \text { Blankes (Tvl) } & 311755 & 417585 & & 503157 & 502000 \\ \text { Swartman } & 1500844 & 2739450 & 4223651 & 3464866 & \text { ongeveer 5 } \\ \text { (R.S.A., } & & & & & \text { tot } 6 \text { mil- } \\ \text { Transkei, } & & & & \text { joen (my } \\ \text { Bophutatswana) } & & & & & \text { projeksie) }\end{array}$

Die 1979-syfers sluit Transkei en Bophutatswana uit; die 1978-syfers sluit die syfers vir Transkei en Bophutatswana in.

Die syfers vir die totale aantal kandidate wat vir st. 10 ingeskry $f$ het, lyk soos volg: 
Die syfers 1 ir die swartman sluit ook weer die Transkei en Bophutatswana in:

$\begin{array}{lrrrrl} & 1960 & 1970 & 1978 & 1979 & 1980 \\ \text { Blankes (Tvl) } & 7594 & 14802 & & 22430 & ? \\ \text { Swartman } & 957 & 2846 & 9800 & 23000 & \text { Geskat: } \\ & & & & & 50000\end{array}$

Die syfers vir Transvaal soos hier verstrek is, wat 1960 en 1970 betref, gepubliseer in die Onderwysbulletin van Junie 1970. Die syfers vir 1979 kom van voorlopig ongepubliseerde gegewens. Die syfer vir 1980 is $m y$ projeksie.

Die syfers i.v.m. die swartman is verstrek deur die Departement Onderwy's en Opleiding.

Wat die blankes betref, is daar vanaf 1973 'n duidelike daling in die geboortesyfer en vanaf 1976 'n skerp afname in immigrante.

Wat die swartman betref is die huidige persentasie-aanwas, soos vroeër gestel, van die hoogste in die wêreld.

Ewewel: hoe ons die hele toneel ook mag beskou, daar is een groot vriag wat steeds sterker na vore kom en wat meermale by ons 'n gevoel van beklemming laat ontstaan: sal ons beperkte hulpbronne uiteindelik nog instaat wees om so ' "mensdom" aan die gan ${ }_{\dot{i}}$ te hou?

Finergieverskaffing, nie alleen aan ons nywerhede nie, nee boweal alan dic mens self - sy voedsel - lê in die swaartepunt van al die probleme wat sentrecr om dî benutting en verbruik van ons hulpbronne.

Tegnokrasie in 'n vertegniseerde maatskappy - dié proses gaan voort. Dje weten skap staan nie stil nie. Al die werktuie wat die mens steeds maar onlwikkel vir s! gerief en die vergemakliking van sy lewe verg vir hulle werking voordurend micr en meer energie. Die groeiende mensemassas vra al meer kos. Inderdaid, die rail!s dring hom aan ons op: lê wat ons energievoorsiening betref êrens vorentoc nic " stolpunt, 'n breekpunt nie?

Hier lê die uitdaging aan, maar ook die geleenthede vir die jong welenskiplithe. 


\section{Uitdagings vir natuurwetenskaplikes}

Stutterheim (1969) het tien jaar gelede, by geleentheid van die Eeufeesvierings van ons universiteit, in die vooruitsig gestel, dat sommige van die innovasies wat teen die einde van die eeu waarskynlik sal word, die volgende is:

* Grootskaalse toepassing van lasers vir doeleindes van akkurate meting, kommunikasie, verwarming, energie-oordrag en beligting.

* Algemene gebruik van supersonıese passasiersvliegtuie en eksperimentele aanwending van vuurpyle vir aardverkeer

* Betroubaarder weervoorspelling op langer termyn deurdat 'n massa inligting verkry van weersatelliete en ander bronne deur rekenouromate van ongekende grootte verwerk sal word.

* Nuwe energiebronne vir oppervlaktevervoer, waaronder vervoer met lugkussingvoertuie aangedryf deur elektromagnetiese velde.

* Goedkoop ontwerp en produksie van items deur geprogrammeerde analise en outomatiese produksietegnieke.

* Nuwe of verbeterde gebruikmaking van die rykdomme van die oseane, onder andere op die gebied van mynbou, voedselvoorsiening, vars water en energie.

* Driedimensionele fotografie, illustrasie en televisie.

* Progressiewe meganisasie of selfoutomatisasie van die huishouding.

* Gebruik van kernplofstowwe vir/uitgrawings en in die mynbou.

* Algemene toepassing van outomatisasie en beheerstelsels in bestuur en produksie.

* Sentralisasie van inligting in hoësnelheiddataverwerkers.

* Gevorderde tegnieke om klimaat te beinvloed.

* Algemene en aansienlike verhoging van die verwagte lewensduur, sowel as 
verjongingstegnieke.

* Permanentbemande satelliete en nedersettings op die maan en op Mars.

* Ten volle geoutomatiseerde winkels.

* Chemiese metodes om die geheue en die leerproses te verbeter.

* Nuwe en verbeterde materiale vir geboue, waaronder glas met 'n veranderbare deurlaatbaarheid.

* E.konomiese waterontsouting op groot skaal.

* Grootskaalse gebruik van rekenoutomate vir intellektuele en professionclc bystand, waaronder vertaling, die opspoor van bronne in die literatuur, mediese diagnose, verkeersbeheer en die opsporing van misdadigers.

* Ekonomiese wêreldwye snelvervoer van mense en vrag.

* Kunsmane en ander metodes om stede snags te verlig.

Prof. Everson van ons Departement Ingenieurschemie noem t.o.v. soos hy dit self stel, die uitdaging aan die gegradueerde natuurwetenskaplike en ingenieur in die energie-bewuste dekade, die volgende:

* Son-energie: Suid-Afrika kan baie put uit hierdie bron; die probleem is dic berging daarvan.

* Windenergie: die benutting of inspanning hiervan is ' $n$ algehele ingenieursprojek.

* Energie van biologiese bronne (etanol): dit is 'n baie belangrike aspek wat in belangrikheid $\mathrm{m} / \mathrm{g}$ steeds toeneem. Die gedagte van die gebruik van afialprodukte maak dit baie aantreklik. Dit kan egter nooit die hoofbron van energie word nie.

* Seebrander-energie: dit is 'n betreklik nuwe idee wat nog maar net aangeraak is. 
In verband met die aanwending van die huidige bronne van energie noem hy:

* Steenkoolverwerking langs die roete van petrol en diesel: dit gaan in dié veld veral om katalisatore wat baie beter benut kan word. Die doel is om meer doeltreffend gebruik te maak van ons kosbare reserwes van steenkool.

* Steenkoolvervloeiing direk van steenkool: hiervcor bestaan daar nog geen aanleg nie en die proses kan deurslaggewend wees i.v.m. winning van vloeibare brandstof uit steenkool.

* Aardgasverwerking: dit behels die gebruik van aardgas (metaan) vir die vervaardiging van vloeibare brandstof, soos metanol.

* Beter gebruik van steenkool by kragstasies. Elektrisiteit bly belangrik en elektriese motors word vinnig ontwikkel.

* Kernenergie: meer vertroue moet ten opsigte hiervan ontwikkel word, veral met betrekking tot veiligheid.

* Vervaardiging van waterstof: dit is 'n baie waardevolle produk wat in verskillende verbindings gebruik kan word.

Wat die natuurwetenskappe betref vind, ten spyte van die waterstofbom, kernslagkoppe, die laserstraal, olie uit steenkool en wat dies meer sy, die mees revolusionêre ontwikkeling in die veld van die Biologie, di. die lewenswetenskappe, plaas. Uit die veelvoud van ontwikkelinge noem prof.J.A. van Eeden, hoof van ons departement Dierkunde vanmôre nog die een ontwikkeling wat my geskud het: die mens steek sy hand uit na die mikromanipulering van die genetiese materiaal binne die selkern. Dit kan die genetika, die erflikheidseienskappe, ook van die mens aantas en verander. Dit plaas 'n geweldige mag in die hand van die mens. Dit het my dadelik laat dink aan Psalm 8: "U het hom weinig minder gemaak as 'n goddelike wese".

Maar toe kom ook die geskiedenis van die toring van Babel by my op: "Toe kom die Here af om die stad en die toring te sien wat die mensekinders aan't bou was. En die Here sế: daar is hulle nou een volk en het hulle almal een taal. En dit is net die begin van hulle onderneming; nou sal niks vir hulle meer onnoontlik wees van wat hulle van plan is om te doen nie". 
Hierdie saak kan eigelik nie aangesien word as 'n uitdaging aan 'n jong wetenskaplike nie. Ons staan hier voor 'n duiselingv: ekkende afgrond. $\mathrm{Al}$ wat ek kan sê is: nee, ons mag nie, nie dit nie! En hy wat dit doen, moet weet wat hy doen. Die verantwoordelikheid is verskriklik en die verantwoording wat gevra sal word, ewe verskriklik.

Dit is nou duidelik: die beskawingsdruk plaas 'n geweldige verantwoordelikheid op die skouers van $u$, jong geleerdes.

En nou is dit so dat in ons bestel, die R.S.A., die oorgrote deel van die ondernemersinisiatief deur die blanke bevolking verskaf word.

Tussen hakies: was dit nie ook so in Mosambiek en is dit nie nog so in Zimbabwe nie?

Maar wat die R.S.A. betref: ek het reeds gesê u is die meningsvormers, die beleid makers van môre. Die ondernemersinisiatief moet van $u$ kom! Ons hoor dit deesdae vroeg en laat oor die radio en televisie en ons lees dit vroeg en laat in ons koerante: ons het 'n groot tekort aan hoë-vlak opgeleide mannekrag, mannekrag met ondernemersinisiatief, mannekrag wat kan beplan, beheer en bestuur en ondernemings kan aanpak.

Dit spreek vanself dat die blankes hulle potensiaal in hierdie verband tot die maksimum moet ontgin en ontwikkel. Dat ons universiteite hier 'n baie groot, groot bydrae moet lewer le voor die hand. En hier land ons dan nou in "volle volume" by die vraag van die plek, die taak, funksie en verantwoordelikheid van die universiteit binne ons volkshuishouding.

\section{Die universiteit en die lewering van mannekrag}

Gewoonweg word die funksie en taak van die universiteit gestel as:

* oordrag van kennis, d.w.s. opleiding van die student

* ontwikkeling van kennis, d.w.s. navorsing

* regstreekse diens aan die gemeenskap.

Ek wil dit effens anders stel: 
* uitbreiding en verbreding van kennis op alle terreine en vlakke d.m.v. oordrag van kennis en navorsing

* die vcrming van die student as mens en meer bepaald die intellektuele vorming van die student as denkende, onderskeidende en beginselbewuste mens. Karaktereienskappe soos leiersvermoë, vlyt, wetenskaplike integriteit, eerlikheid, ens. sal in die student ontwikkel en tot ontplooiing kom deur o.a. self-dissipline en sy studie, die beoefening van die wetenskap en die daaglikse omgang met dosente en studente

* opleiding vir bepaalde professies waarby 'n hoë mate van oorspronklike denke en wetenskaplike kennis vereis word en nie vir professies waarby slegs bepaalde vaardighede te pas kom nie

* regstreekse diens aan die gemeenskap.

Elkeen van hierdie funksies hou verband met die dilemma van ons situasie. Kom ons kyk net na punt nommer een: uitbreiding en verbreding van kennis op alle terreine en vlakke d.m.v. oordrag van kennis en navorsing. Waarom sal dit anders gaan hier as om juis die probleme en behoeftes van die gemeenskap waaruit die universiteit voortkom en waarbinne dit staan?

Hoe dit ookal sy, die universiteit lewer die oorgrote deel van die hoë-vlak mannekrag wat nodig is in omtrent al die sektore van die volkshuishouding. Ek het ook gesê dat die oorgrote deel van die ondernemersinisiatief deur die blankes in hierdie land gelewer word. Maar nou die vraag: Sal dit, teen die agtergrond van die getalle wat ek pas genoem het, vir die blankes nog moontlik wees om die nodige hoc̈-vlak mannekrag te lewer wat nodig is om ons ekonomiese ontwikkeling en groei te handhaaf en die bykomende eise wat spruit uit ons besondere politieke en militêre probleme?

Jin dan 'n verdere vraag: Kan ons universiteite hierdie funksie vervul, naamlik die lewering van die hoë-vlak mannekrag wat nodig is?

King en Pratt (1978) het 'n studie van hierdie vraagstuk gemaak. Dit gaan vir hulle naamlik om:

* die voorsiening van opgeleide en geskoolde mannekrag (ek sal hierna verwys as hoë-vlak mannekrag) en 
* vlak van navorsing en ontwikkeling in die breë gebiede van die natuurwetenskap, die ingenieurswese en die tegniek/tegnologie (NIT).

Dit is 'n bekende feit dat daar vir 'n ruim aantal jare al 'n groot tekort is aan goedopgeleide onderwysers vir Wiskunde en veral die Natuurwetenskap, ofte wel SkeiNatuurkunde vir die sekondére skool. En hierdie saak is reeds oor en oor bespreek by baie geleenthede en daaroor is baie geskryf. Dit gaan vir ons nou hier om die toedrag wat voorgenoemde twee punte betref meer bepaald op die tersiére, d.w.s. universiteitsvlak.

Dit is onmoontlik, maar ook onnodig om die hele betoog van die professore King en Pratt hier te probeer volg. Ons sal enkele belangrike punte uitlig. Belangrik is hulle slotsomme en die vraag of ons met hulle kan saamstem. Met die gegewens tot hulle beskikking tref hulle 'n vergelyking tussen die toedrag by ons en $0 . a$. in twee ander vergelykbare lande t.w. Kanada en Australic. Voordat ek hulle slotsomme hier verstrek, wys ek graag daarop dat ek tot hiertoe die probleme waarvoor ons staan, en daarmee die dilemma van ons situasie in baie breë trekke probeer skets hèt. Ek het my slegs by breë trekke bepaal omdat die tyd ons nie toelaat om in detail in te gaan op al die ter sake faktore in die verband nie. Ek wil dit tog beklemtoon dat ons omstandighede ook enigsins anders is as dié in Australië en Kanada: die militêre situasie hier, as deel van ons oorlewingstryd, verg van ons dat ons "drastiese" aandag sal gee aan die lewering van hoë-vlak mannekrag en aan navorsing en ontwikkeling ( $\mathrm{N} \& \mathrm{O}$ ).

King en Pratt (1978, p. 1 - 12) stel dit dan dat ons na aanleiding van die twee genoemde punte t.w. die lewering van hoek-vlak mannekrag en $\mathrm{N} \& \mathrm{O}$ graag die volgende vrae sal wil beantwoord:

* Wat is die algemene neiging wat genoemde twee sake betref in ons land?

* Wat is ons land se behoeftes in hierdie verband vir die volgende vyf tot tien jaar, d.w.s. wat moet die posisie wees?

* Wat is die tekortkominge, die bottelnekke?

* Wat is die oorsake, die oorsprong van die huidige tekortkominge?

* Wat moet gedoen word? 
Ons kan nie al vyf hierdie vrae saam met hulle in detail probeer beantwoord nie. Ons wil aansluit by ons vroeëre opmerking dat ons ons sal bepaal by hulle slotsomme en die vraag in hoeverre ons met hulle kan saamstem. Ek haal hulle aan:

Ons het hoë-vlak mannekrag nodig om

* ons ekonomiese ontwikkeling en groei te handhaaf en in hierdie opsig moet ons nie veel verskil van ander vergelykbare lande nie;

* die bykomende eise wat die gevolg is van ons besondere politieke en militêre probleme, te bevredig.

Hierby moet nou in gedagte gehou word dat

* daar 'n toenemende druk in ander lande is om ons toegang tot hulle tegnolo. gie te ontsê, d.w.s. 'n druk om ons in die verband te boikot;

* ons 'n toenemende behoefte het om militêr paraat te wees, d.w.s. 'n toenemende behoefte het om in hierdie verband navorsing en ontwikkeling te doen i.v.m. wapentuig;

* 'n groeiende behoefte het aan werksgeleenthede vir die swart man. Ek verwys in die verband na die bevolkingsyfers wat ek vroeër genoem het.

Wat navorsings- en ontwikkelingsmannekrag betref, vergelyk ons soos volg met Kanada en Australië:

\section{Kanada Australië Suid-Afrika}

$1969 \quad \begin{array}{llll}1,3 & 1,1 & 0,6\end{array}$

$\begin{array}{llll}1971-1,2 & - & 0,6\end{array}$

Ten opsigte van N \& O-mannekrag per 1000 van die totale arbeidsmag noem ek enkele syfers uit die memorandum van King en Pratt:

$\begin{array}{llll}\text { Kanada: } & 1963 / 64 & - & 4,3 \\ & 1967 & - & 5,9 \\ & 1971 & - & 5,8 \\ \text { Australië: } & 1969 & - & 7,3 \\ \text { Suid-Afrika: } & 1971 & - & 1,6\end{array}$


Dit tref ons onmiddellik dat S.A. hier "anders" is as Kanada en Australië. Ons bestee ' $n$ baie kleiner deel van ons Bruto Nasionale Opbrengs aan navorsing en ontwikkeling as die genoemde twee lande. Dié deel van ons arbeidsmag wat aan navorsing en ontwikkeling werk is verhoudingsgewys nog kleiner. Van hierdie somtotaal is die deel wat bestee word in die staatssektor heeltemal bevredigend, dié bestee deur die sakesektor laag, maar dié bestee in die universiteitsektor skrikwekkend laag.

\section{Die posisie in Suid-Afrika}

Ek noem die volgende syfers weer uit die memorandum van King en Pratt (1978, p. 12 e.v.)

Die totale uitgawe aan navorsing en ontwikkeling tussen 1966/67 en 1973/74 as 'n persentasie van die bruto nasionale produk was 0,59 (hoogste) in 1971/72 en 0,46 (laagste) in 1966/67. In 1975/76 was dit 0,61 . En hoe is die besteding verdeel tussen die staatsektor, die W.N.N.R. alleen, die sakesektor, die hoër onderwys (tersiêre onderwys) en dan ander nie-winsgewende organisasies? Kyk na die volgende syfers (ek gee dit slegs vir twee datums, saaklikheidshalwe):

\section{$1966 / 67 \quad 1973 / 74$}

Staatsektor (WNNR ingesluit)

$$
62,5 \quad 57,3
$$

WNNR alleen

$\begin{array}{ll} & 22,9 \\ 26,8 & 30,6 \\ 7,8 & 11,3 \\ 2,9 & 1,4\end{array}$

Hoër Onderwys

Nie-winsgewende organisasies

Sover dit die universiteite betref, lyk dit of Australië, Kanada en Suid-.Afrika twintig jaar gelede $\min$ of meer in 'n gelykop-posisie was. Sedertdien egter het .tustralië en Kanda 'n kragdadige beleid gevoer om die navorsings- en ontwikkelingsaktiwiteit in die universitere sektor te versterk, 'n beleid wat vir hulle goeie rrugte afgewerp het en 'n beleid waaroor hulle nog nooit spyt was nie.

Ons kan die toedrag soos volg saamvat:

* 'n tekort aan hoë-vlak mannekrag van alle soorte - bestuurs en mannekrag in die natuurwetenskaplike, ingenieurs-en tegniese-tegnologiese veld;

* onderbesteding wat navorsing en ontwikkeling betref in die sakesckior: 
* 'n veels te lae besteding in die universitêre sektor.

In Kanada toon die hele proses van die ontwikkeling van Navorsing en Ontwikkeling drie fases:

$\begin{array}{lrll}\text { fase I } & : & \text { Staatsektor } \\ \text { fase II } & : & \text { Universitêre sektor } \\ \text { fase III } & : & \text { Nywerheids- of sake-sektor. }\end{array}$

Wat die R.S.A. betref kan ons sê dat fase I, d.w.s. navorsing en ontwikkeling in die staatsektor, op 'n prysenswaardige wyse voortgang gehad het en nog het. Wat fase II en III betref moet die R.S.A. gemeet aan die hand van elke moontlike kriterium geklassifiseer word as 'n tipiese onderontwikkelde land.

Dit wil voorkom - en my ervaring as dosent vir 40 jaar lank bevestig dit - asof die toestand wat navorsing en ontwikkeling aan ons universiteite betref, en meer bepaald wat die aantal voltydse studente wat navorsing doen betref, steeds aan die agteruitgaan is.

Ons het hier 'n bose kringloop wat begin by die tekort aan goedgekwalifiseerde onderwysers vir Wiskunde en Natuurwetenskap. Die opleiding wat op sekondêre skool te kort skiet, bring mee dat nie al die leerlinge wat daartoe in staat is die vakke op universiteit neem nie. Die gevolg is weer minder hoë-vlak mannekrag wat gelewer word deur die universiteit oor die hele spektrum van onderwys-ingenieurswese-tegniek-tegnologie-navorsing. Die wat gelewer word moet die behoeftes in al die sektore bevredig: die staats-, universitêre en sake-sektor. Waar daar dan nou nie genoeg gelewer word nie, volg dat 'n skerp mededinging om die beskikbare mannekrag tussen die drie sektore sal plaasvind. Dit is ook die geval. Ongelukkig vir die universiteit kan hy nie kompeteer met die staats- of private sektor nie.

Dit wil voorkom asof ons in die afgelope twintig jaar wat die hele saak van nagraadse studie, navorsing en ontwikkeling aan ons universiteite betref nog nie 'n tree gevorder het nie.

\section{Riglyne vir 'n beter bedeling}

Dit lei geen twyfel dat nagraadse studie, navorsing en ontwikkeling aan ons universiteite tot die maksimum waartoe ons in staat is, gestimuleer moet word nie. Daartoe sal die hele situasic rondom gevorderde studie, navorsing en ontwikkeling aan 
die universiteit opnuut bekyk moet word.

Ek pleit dus vir 'n herwaardering deur ons hoë owerheid van die plek, die funksie en die taak van die universiteit in ons samelewing.

Die universiteit moet in staat gestel word om 'n groter bydrae te lewer, as wat tans die geval is, in die navorsings- en ontwikkelingsektor.

Daartoe sal beter finansiële steun van die kant van, in die eerste plek, ons owerheid nodig wees, maar ook van die kant van ons nywerhede ten einde die universiteit in staat te stel om die nodige fasiliteite juis vir gevorderde studie, navorsing en ontwikkeling daar te stel. In hierdie verband juis, moet die universiteit in staat gestel word om te kompeteer met die staatsektor en nywerheidsektor.

Ek pleit nie dat die universiteite ingestop moet word met geld en dan maar die vryheid moet hê om daarmee te doen wat hy wil nie. Ook hier sal beplanning nodig wees, en die nodige verantwoording sal gevra moet word. Die universiteit sal die resultaat moet lewer. Maar dit help nie om 'n man net tot onder die broodlyn te voed en dan te sê hy kan nie sy werk doen nie, hy beteken niks nie.

Prof. Rudi van Eldik het in sy inougurele rede nou onlangs dit gestel dat die chemiedosent in die R.S.A. gemiddeld 32 uur per week bestee aan voorbereiding vir sy teorie- en praktiese klasse en die waarneem van die klasse en die praktiese werk en die kontrolering van die studente se werk. Van 'n veertig-uur werksweek bly dus presies 8 uur oor vir ondersoekings- en navorsingswerk. Rudi van Eldik is vandag professor in Duitsland waar die omstandighede hom toelaat om ook rustig navorsingswerk te doen.

Ek weet dat die universiteit in hierdie verband vir soveel tiental jare al 'n stroom van kritiek moes verduur. Ek het egter die hele verloop van hierdie aangeleentheid nou vir $\mathbf{4 0}$ jaar lank aan hierdie universiteit meegemaak. Ek was ook vir nege jaar lank dekaan van die Fakulteit Natuurwetenskappe en, wat ek kan noem, die geworstel in byna elke departement in die fakulteit om tot iets te kom, iets tot stand te bring, van naby meegemaak. Werklik, daar kan nie gesê word dat die personeel nie probeer het om hulle kant te bring nie. Vanselfsprekend sal daar uitsonderings wees; vanselfsprekend kon daar in sommige gevalle harder geprobeer gewees het en vanselfsprekend moes die beplanning in sommige gevalle baie anders gewees het. 
Tweedens pleit ek dat daar opnuut gekyk word na die oessic daarvan dat so min studente juis die basiese natuurwetenskappe as studierigting kies. Dit is baie moontlik dat juis die tekort an goedopgeleide onderwysers vir die vakke een van die oorsake is omdat juis dan die onderwys van die vakke op die middelbare skool in meer as een opsig te kort skiet. Maar ek is oortuig daarvan dat een van die fundamentele en mees belangrike oorsake die swak vooruitsigte vir 'n lonende loopbaan is vir die kandidaat wat juis van die basiese natuurwetenskap 'n loopbaan wil maak. Juis as gevolg van die swak vooruitsigte kies die kandidaat liefs 'n loopbaan in 'n toegepaste rigting bv. medisyne en selfs ingenieurswese.

Derdens pleit ek dat alles moontlik gedoen sal word om ons potensiaal in hierdie verband, d.w.s. leerlinge en studente wat die vermoë besit om van hierdie wetenskappe 'n suksesvolle loopbaan te maak vroegtydig te identifiseer en hulle aan te moedig om juis in die rigting te studeer.

Hier staan ons juis voor die dilemma dat identifikasie grotendeels reeds op die sekondêre skoolvlak moet gebeur en daar skiet ons onderwys te kort. Hier sal ook baie meer beurse nodig wees vir die verdienstelike of merietevolle kandidaat.

Vierdens pleit ek daarvoor, dat soos gestel in die aanhaling uit die verslag van 1961 aan die Fakulteitsraad, dit 'n saak van beleid moet word dat elke kandidaat wat die B.-graad behaal en wat die vermoë het om nagraadse studie suksesvol te onderneem, daartoe in staat gestel moet word.

Hierdie pleidooi geld vir alle vakke, nie slegs die natuurwetenskappe nie en ook t.o.v. alle universiteite, d.w.s. die universiteite van alle volksgroepe.

Dit is juis, soos vroeër gestel, die aktiwiteit rondom die nagraadse of gevorderde studie en die navorsing wat 'n universiteit in die ware sin van die woord universiteit maak. En sukses en prestasie stimuleer die student en dosent; dis aansteeklik en bevrugtend juis wat studie en navorsing betref. Ons volkshuishouding het hierdie mense so broodnodig.

Ek het net gistermôre oor die radio na 'n minister geluister toe dit gegaan het om die bekombaarheid van gevorderde mannekrag vir sy department én salarisse. Hy het dit gestel dat sou hy, om personeel te bekom, die salarisse verhoog, die privaatsektor van sy kant af, om sy personeel te bekom ook maar net weer salarisse sal verhoog - weer 'n bose kringloop. Maar hier, dan, word die oorsaak van die dilemma blootgelê: te min opgeleides wat die werk kan doen. 
Sou dit 'n saak van beleid word om elke kandidaat wat die potensiaal besit in staat te stel om voltyds nagraads te studeer, ek herhaal voltyds nagraads aan 'n universiteit, want dit is my pleidooi, dan sal, dit is voor-die-hand-liggend, besin moet word oor die finansiëring van hierdie studie. Dit wil my voorkom as 'n baie kortsigtige beleid om 'n kandidaat tot by die B.-graad te bring en dan sy potensiaal nie verder te ontwikkel met die oog dan op arbeid op 'n hoër vlak, d.w.s. meer produktiewe arbeid nie. Om 'n beeld te gebruik: dit loon nie om 'n diamant halfpad te slyp nie.

Die kandidaat met die potensiaal wat nagraads wil voortgaan, sal daartoe in staat gestel moet word, sonder dat hy voel dat hy 'n agterstand ontwikkel teenoor sy maat wat na drie jaar van studie begin werk. Dit kan gedoen word deur op 'n ruim basis voorsiening te maak vir tydelike assistentskappe.

Kom ons vergelyk die posisie van twee kandidate wat albei vir die doktorsgraad werk, albei in die Gronddierkunde, die een aan die PU vir CHO onder leiding van ons dr: G C Loots en die ander by die Departement Landbou, dus 'n staatsinrigting. Die man wat by ons studeer moet, tensy hy 'n beurs of 'n tydelike assistentskap het, betaal vir sy studies met geld wat hy leen of geërf het. Laasgenoemde word betaal; hy kry 'n goeie salaris. Die navorsing wat albei doen is ' $n$ bate vir die staat: albei ewe goed. Hoe kan ons dan kompeteer met die staatsektor? Ek het gepleit vir 'n herwaardering van die plek, funksie en taak van die universiteit. Kan ons wat navorsing en ontwikkeling betref in hierdie verband, d.w.s. wat die fasiliteite en geleenthede wat ons die kandidaat bied, nie gelykgebring word nie?

Vyfdens wil ek pleit dat die posisie van die student wat gevorderde studie doen of wil doen ook nog uit 'n ander oogpunt herwaardeer word.

Ons seuns doen twee jaar militêre diens. Dit dra ons almal se goedkeuring en heelhartige ondersteuning weg. Maar na die twee jaar begin hy met sy B.-graadstudie wat ' $n$ minimum duur van drie jaar het. Vyf jaar na matriek dus, kry hy die B.-graad. En die gewone gang is dat hy nou begin dink aan 'n lewensmaat. Daardie student moet nou besluit: Ek gaan werk en trou of stel die gedagte aan 'n lewensmaat vir eers maar af en studeer met 'n tydelike assistentskap met 'n karige vergoeding of nog kariger beurs. Ook dus in die verband pleit ek vir tydelike assistentskappe met 'n ruim besoldiging en - en hierdie punt wil ek baie sterk beklemtoon - ondersteuning van die staat aan die universitcit vir oprigting vall koshuise vir getroude pare op dieselfde basis, ten minste, as wat die universitcit nou kry vir die oprigting van koshuise vir ongetroude studente. Tans kry dic 
universiteit nie ondersteuning van die staat vir die oprigting van koshuise vir getroude pare nie.

Tot dusver het my betoog byna uitsluitlik gehandel oor ons probleme i.v.m. ons oorlewingstryd - ons fisiese bestaan. En in hierdie verband het dit dan hoofsaaklik gegaan oor energievoorsiening en wat die mens betref, het ek gesê gaan dit finalitêr om voedselvoorsiening. Van brood alleen kan mens egter nie lewe nie!

Ek het dit vroeër gestel dat ons in 'n vertegniseerde maatskappy lewe. En die teg niek, onderskraag deur die natuurwetenskap ontwikkel, en dit menslikerwys gesien, uit die brein en die hand van die mens, byna onbeheersd en sonder perke.

In die paradys het God aan die mens opdrag gegee: "Wees vrugbaar en vermeerder en vul die aarde, onderwerp dit en heers oor die visse van die see en die voëls van die hemel en oor al die diere wat op die aarde kruip". En: "Ek gee aan julle die plante wat saad gee, wat op die hele aarde is en al die bome waar boomvrugte aan is wat saad dra. Dit sal julle voedsel wees".

Die kultuuropdrag van God aan die mens is duidelik: "Vul die aarde, onderwerp dit". Deur die natuurwetenskap en die tegniek het die mens inderdaad geweldige mag oor die stoflike "dinge" bekom. Deur o.a. die omskepping van die potensiële energie uit die natuur in bewegingsenergie (dink o.m. aan die stoomenjin en die elektriese motor) het die mens geweldige magsmiddele in sy hand bekom. Hy kon nou die wêreld se energie- en ander hulpbronne op 'n massale skaal aanwend in sy diens. Meer werktuie van allerlei aard en soort is ontwikkel en verbeter totdat vandag elke faset van sy lewe afhanklik is van die werktuie, dermate dat sy hele bestaan in die greep daarvan lê. Dink in die verband maar net aan die rol wat die volgende in u lewe speel: die motorkar, die radio, die televisiestel - om maar 'n drietal uit die duisende te noem.

Inderdaad, die mens het mag oor die natuur."dinge" gekry. Dink ook nog aan die bomme op Hirosjima en Nagasaki, die ruimtetuig wat foutloos na die maan en terug geloods is, aan die vliegtuig wat mense op massale skaal vervoer, e.s.m.

Maar nou, omgekeerd het die wetenskap en die tegniek ook mag oor die mens gekry. Die wetenskapsmag en die mag van die tegniek het faktore van enorme betekenis in die hele lewensopset van die mens en dis van sy ganse kultuur geword.

Nie slegs het die mag van die wetenskap en van die tegniek die menslike samelewing 
ingrypend verander nie, maar dit het ook daaraan 'n uiters dinamiese karakter gegee. Dit het die samelewing die wêreld oor in 'n stroomversnelling laat beland wat afstuur (of is ons al daar?) op 'n turbulente "establishment" waarin die mens homself in die middelpunt geplaas het, met 'n gevolglike verabsolutering van norme wat hyself "geskep" het ter wille van homself. En dis grootliks die mag van die wetenskap en die tegniek wat hom daartoe gebring het. Sekularisme, massifikasie, dirigisme, ontpersoonliking en vernietiging van die mens se "eiewaarde", ontluistering van die arbeid, besoedeling van sy eie bestaansmilieu, het reeds al meer as tendense in hierdie maatskappy geword. In vele opsigte is hulle kenmerkend daarvan. Spanning van allerlei aard en vorm is aan die orde van die dag. En in hierdie maalstroom is die menslike vryheid ingesuig en swaar aangetas.

Maar genoeg hiervan. Vir die Christen, die gelowige, lê die sin in die tegniek daarin dat dit 'n geskenk van God is waarmee hy sy skeppingsopdrag kan volvoer. Met ander woorde, hy is geroep tot die beoefening van die wetenskap en die tegniek en die benutting van die bronne wat die tegniek moontlik maak, maar die beoefening en die benutting is normgebonde: alles in diens en tot eer van God. Die kragte van die natuur waaroor die mens met sy mag beskik sowel as die mag van die mens self, vind hulle oorsprong in die krag, mag en soewereiniteit van God. Om hierdie rede is beoefening van die wetenskap en die tegniek, die uitvinding, vervaardiging en gebruik van tegniese middele 'n waaragtige menslike goed, wat ten volle positief beoordeel en gewaardeer moet word (Stoker, 1971, p. 247).

Die gelowige mens weet dat die natuurwetenskap en die tegniek vir hom gevaar inhou. Maar boweal weet hy dat God alle dinge geformeer het en die lot van alle dinge in sy hand hou. God bestier alle dinge en alle dinge word deur Christus nuut gemaak. Hier lê sy heilsverwagting en verwerp daarom die doemprofesie oor die natuurwetenskap en die tegniek. Hy ken geen wêreldangs nie, maar die liefde van God wat in die kruisdood van Christus aan hom bevestig is (Stoker. 1971 , p. 249).

\section{BIBLIOGRAFIE}

AKINBODE, Ake. 1977. Population explosion in Africa and its implications for economic development. Journal of geography, Jan 1977.

KING, R.P. en PRATT, J.M. 1978. Memo on the science-engineering-technology situation in R.S.A. Johannesburg; University of the Witwatersrand. 
RAAD VAN EUROPA. 1976. Proceedings of a seminar held by the Council of Europe in the implications of a stationary or declining population in Europe. Strassbourg: Council of Europe.

SADIE, J.L. 1973. Projeksies van die Suid-Afrikaanse bevolking. Johannesburg: Nywerheid-Ontwikkelingskorporasie.

SADIE, J.L. 1974. Bevolkingsgroei en teskawingsdruk. (In: Suid-Afrikaanse Akademie vir Wetenskap en Kuns. Die mens en sy beperkte hulpbronne. Pretoria.)

STOKER, H.G. 1971. Mens en tegniek vandag. (In Besinning en uitsig. Potchefstroom: PU vir CHO.)

STUTTERHEIM, N. 1969. Fisika en ingenieurswese in die toekomstige ontwikkeling van Suid-Afrika. Ongepubliseerde referaat gelewer op 20 Augustus 1969 by geleentheid van die eeufeesvierings van die PU vir CHO. 